\title{
Revalidation of Ceresa terminalis Walker and its placement in Stictocephala Stål (Hemiptera, Membracidae)
}

\author{
Gabriel S. de Andrade
}

Centro de Ciências Biológicas e da Saúde, Universidade Estadual do Oeste do Paraná. Rua Universitária 2069, Caixa Postal 711,85819-110 Cascavel, Paraná, Brasil. E-mail: gsa@certto.com.br

\author{
ABSTRACT. Ceresa terminalis Walker, 1851 is reinstated and transferred to Stictocephala Stål, 1869: Stictocephala terminalis \\ (Walker, 1851) sp. rev., comb. nov. \\ KEY WORDS. Ceresini, Membracoidea, Smiliinae, systematics, taxonomy.
}

RESUMO. Revalidação de Ceresa terminalis Walker e sua alocação em Stictocephala Stål (Hemiptera, Membracidae). Ceresa terminalis Walker, 1851 é revalidada e transferida para Stictocephala Stål, 1869: Stictocephala terminalis (Walker, 1851) sp. rev., comb. nov.

PALAVRAS CHAVE. Ceresini, Membracoidea, sistemática, Smiliinae, taxonomia.

\section{Stictocephala terminalis (Walker) sp. rev., comb. nov.}

\section{Figs $1-2$}

Ceresa terminalis Walker, 1851: 528.

Ceresa terminalis; Broomfield, 1971: 380 (typ.); McKamey, 1998:

$$
244 \text { (cat., = C. brunnicornis (Germar, 1835)). Error. }
$$

ButLer (1877) placed Ceresa terminalis Walker in the synonymy of Ceresa axillaris (Germar, 1835) and GoDING (1929) in the synonymy of C. brunnicornis (Germar, 1835). The comparative study of the original description and of the female holotype of C. terminalis Walker, deposited at "The Natural History Museum" (London), with material considered as C. axillaris (Germar), following the interpretation of RemEs-LenICov (1973) and ANDRADE (2004), showed that they are different species, confirming the observations of REMES-LENICOV (1973). The same conduct with relation to C. brunnicornis (Germar), showed that they are also different species.

The study of the holotype allowed us to classify the species in the genus Stictocephala Stål, 1869, very close of S. taurina (Fitch, 1856) and S. tauriniformis Caldwell, 1949.

\section{ACKNOWLEDGEMENTS}

I am indebted to Mick D. Webb (The Natural History Museum, London, UK), for the courtesy during my visit to the Institution and opportunities for the studies in the Membracidae collections.

\section{REFERENCES}

Andrade, G.S. 2004. As espécies do gênero Ceresa Amyot \& Serville (Hemiptera, Auchenorrhyncha, Membracidae). Revista Brasileira de Zoologia, Curitiba, 21 (4): 671-738.

Broomfield, P.S. 1971. A catalogue of the Membracid types (Homoptera: Membracidae) in the British Museum (Natural History). Bulletin of the British Museum of Natural History, London, 25 (8): 325-386.

ButLER, A.G. 1877. On various genera of the homopterous family Membracidae with descriptions of new species. Cistula Entomologica, London, 2: 205-222.

Goding, F.W. 1929. The Membracidae of South America and the Antilles. IV. Subfamilies Hoplophorioninae, Darninae, Smiliinae, Tragopinae (Homoptera). Transactions of the American Entomological Society, Philadelphia, 55: 197-330.

McKameY, S.H. 1998. Taxonomic catalogue of the Membracoidea (Exclusive of Leafhoppers) - Second supplement to Fascicle 1 - Membracidae of the General Catalogue of the Hemiptera. Memoirs of the American Entomological Institute, Gainesville, 60: 1-377.

Remes-Lenicov, A.M.M. 1973. Contribución al estudio de los Membrácidos neotropicales I. Revisión del género "Ceresa" (sic) Amyot et Serville. Acta Zoologica Lilloana, Tucuman, 30: 53-134.

WALKER, F. 1851. List of the specimens of homopterous insects in the collection of the British Museum. London. 2: 261-636. 

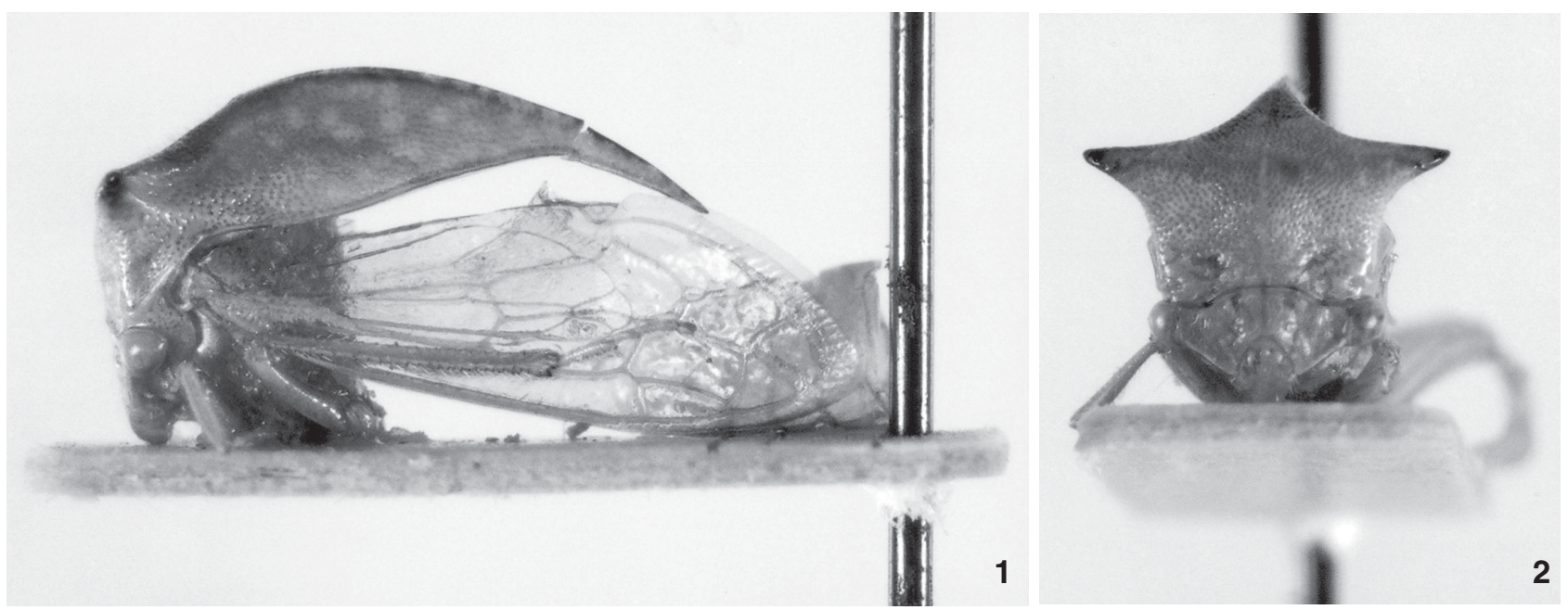

Figures 1-2. Stictocephala terminalis, male, compared with the type: (1) left lateral view; (2) frontal view.

Received in 22.III.2005; accepted in 28.VIII.2005. 